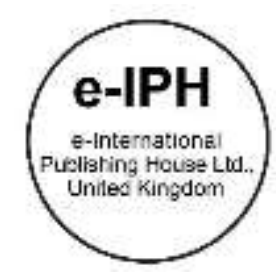

\title{
The Tree Vandalism Model (Tvm): Quantifying urban tree vandalism status
}

\author{
Helmi Hamzah ${ }^{1 *}$, Noriah Othman ${ }^{2}$, Nur Huzeima Mohd Hussain ${ }^{1}$ \\ 1 Department of Landscape Architecture, Faculty of Architecture, Planning and Surveying, Universiti Teknologi MARA Perak Branch, Seri \\ Iskandar Campus, 32610 Seri Iskandar, Malaysia \\ 2 Centre of Studies for Landscape Architecture, Faculty of Architecture, Planning and Surveying, Universiti Teknologi MARA Selangor Branch, \\ Puncak Alam Campus, 42300 Bandar Puncak Alam, Malaysia \\ helmi692@uitm.edu.my,noriaho@yahoo.com, nurhu154@uitm.edu.my
} Tel: +6019 2806604

\begin{abstract}
The Tree Vandalism Model (TVM) was developed to assist decision-makers and tree managers to quantify the status of tree vandalism incidence in the urban area. The model quantifies tree vandalism incident influenced by the shortcoming of tree conditions, tree vandalism incident derived from human error and tree vandalism incident due to lack of urban tree concern; which that interpret the number of tree vandalism throughout the area; the tree vandalism composite index value throughout the area; and a tree vandalism classification.
\end{abstract}

Keywords: Composite Index, Tree Vandalism, Urban Stresses, Urban Tree Care.

eISSN: 2398-4287@ 2021. The Authors. Published for AMER ABRA cE-Bs by e-International Publishing House, Ltd., UK. This is an open access article under the CC BYNC-ND license (http://creativecommons.org/licenses/by-nc-nd/4.0/). Peer-review under responsibility of AMER (Association of Malaysian Environment-Behaviour Researchers), ABRA (Association of Behavioural Researchers on Asians/Africans/Arabians) and cE-Bs (Centre for Environment-Behaviour Studies), Faculty of Architecture, Planning \& Surveying, Universiti Teknologi MARA, Malaysia.

DOI: https://doi.org/10.21834/ebpj.v6iSI4.3031

\subsection{Introduction}

Few research discusses the effect and affects of affliction experienced by trees in urban areas. Many urban trees in most of the cities whether they are newly planted or mature exhibit serious deterioration (Koeser, Hauer, Norris, \& Krouse, 2013; Nowak, Joe, \& Beatty, 1990; Roman, Battles, \& McBride, 2014) due to the urban stressors exposure especially in social factors (Hasan, Othman, \& Ismail, 2017; Zaragoza Hernández et al., 2015). Tree vandalism expressed a social issue that dedicates a foundation for tree health decline and leads to mortality (Zaragoza Hernández et al., 2015). Usually more than half of the tree population will die as a result of serious pests and diseases infectious stems from vandalism injury (Nowak et al., 1990; Zaragoza Hernández et al., 2015). Hence, the thought of 'urban stresses' positioned an important of the criteria for tree vandalism incidence and establishing an appropriate urban tree monitoring model. In so doing, assessing the tree vandalism incident is one of the initial steps towards understanding the issues in developing appropriate prevention and remedial action plans (Richardson \& Shackleton, 2014; Zaragoza Hernández et al., 2015). Understanding and quantifying the status of tree vandalism incidence is an important prerequisite in managing urban trees for optimal tree growth and longevity.

The Tree Vandalism Model (TVM) was developed through research on defining and determining an urban tree vandalism incident based on data obtained from tree care experts. This TVM can assist decision-makers and tree managers in evaluating the status of tree vandalism in urban areas. The model incorporates tree vandalism incidence data with criteria and categories weighting to measure the tree vandalism composite index. These models are structured by three (3) categories with thirty-two (32) verified tree vandalism criteria by the tree care experts.

eISSN: 2398-4287@ 2021. The Authors. Published for AMER ABRA cE-Bs by e-International Publishing House, Ltd., UK. This is an open access article under the CC BYNC-ND license (http://creativecommons.org/licenses/by-nc-nd/4.0/). Peer-review under responsibility of AMER (Association of Malaysian Environment-Behaviour Researchers), ABRA (Association of Behavioural Researchers on Asians/Africans/Arabians) and cE-Bs (Centre for Environment-Behaviour Studies), Faculty of Architecture, Planning \& Surveying, Universiti Teknologi MARA, Malaysia.

DOI: https://doi.org/10.21834/ebpj.v6iSI4.3031 
The categories and criteria consists of: (1) Specific motive and action (SMA): the anatomy of tree conditions which quantities vandalism act influenced by the tree conditions (including; location of tree, size of tree, tree health condition, tree growth rates, species of tree, the owner of the tree, tree characteristic, tree debris, tree value and age of tree) (Camacho-Cervantes, Schondube, Castillo, \& MacGregor-Fors, 2014; Foster \& Blaine, 1978; Friar, Gibson, \& Vollebregt, 2012; Gilbertson \& Bradshaw, 1985; Richardson \& Shackleton, 2014); (2) Ideology and practices (IP): composition of the human misconduct that quantities vandalism act derived from human error (including; level of knowledge, rules and regulations, information of tree benefits, design and layout, tree care monitoring, tree maintenance approaches, tree maintenance status, religious and cultural beliefs, coordination and cooperation, demographic (age) and socio-economic status) (Long, 2003; Malek \& Mariapan, 2009; Moore, 2013; OCHA, 2015; Pepper, 2008; Richardson \& Shackleton, 2014); (3) Victim of circumstances (CC): configuration of the anthropogenic stresses, which quantities vandalism act due to lack of urban tree concern (including; conflict with other activities, infrastructure upgrading, priority of space usage, trees cause interference, tree for structure attachment, tree without protective structure, event and occasion, use of tree parts for other purposes, rate of human population, memorial display tree as protective structure) (Gwedla \& Shackleton, 2015; Miller \& Miller, 1991; Nowak, Kuroda, \& Crane, 2004; Richardson \& Shackleton, 2014; Trout \& Brunt, 2014). This Tree Vandalism Model is applicable within the urban and rural areas in various scales and sizes. Comprehensively measuring the tree vandalism incident was evaluated critically in TVM.

\subsection{Data Requirements}

The TVM could be run by using the tree vandalism incidence data consisting of 32 criteria from the three categories; specific motive and action (SMA):10 criteria, ideology and practices (IP):11 criteria, and victim of circumstances (CC):11 criteria. The quantity of vandalism incident data is required to be represented in the respective measurement units (e.g., 65 units of signage attached on tree stem, 15 kids snapped tree brunches, $10 \mathrm{~kg}$ nails nailed on tree stem and $8 \mathrm{~m}^{3}$ root zone excavation). All data should be organized according to the three (3) abovementioned categories. The sign of tree damaged as a form of unsatisfied with the tree conditions that are committed intentionally and planned to modify tree conditions classified in the SMA category. (e.g., overgrown tree canopy removal and ring-barking to the old tree). Meanwhile, a tree damaged occurs in a form of traditional regulation breaking without malicious intent, influenced by human error such as poor skill and lack of an awareness spirit (e.g., build a structure under the tree canopy and widening the road on root zone) classified in IP category. Finally, any damaged tree in intentionally or unintentionally due to anthropogenic activities to achieve the other goals without concern about the tree (e.g., burning rubbish at tree stem and signage attachment at tree stem) are classified in CC category.

\subsection{Analysis}

This model calculates each vandalism incident of criteria normalized score $(a)$, criteria weighting $(b)$, and criteria aggregate $(c)$ to generate an index of tree vandalism throughout the area (Baptista, 2014; Greco, Ishizaka, Tasiou, \& Torrisi, 2019):

$$
\begin{gathered}
\sum_{k, t} a_{k} b_{k} c_{t} \\
k=1,2,3 \ldots 32 \text { and } t=1,2,3
\end{gathered}
$$

where $k=$ criteria, $t=$ category, $a=$ criteria normalized score of assessment area, $b=$ criteria weighting, and $c=$ category aggregate

\subsection{Criteria Normalized}

In identifying tree vandalism incidents involves the subjective criteria, the Min-Max Normalization technique used in normalizing all criteria score (Mazziotta \& Pareto, 2013). These techniques are made to compare the criteria score due to differences in measurement units. This procedure refers to linear transforming on the original range of data that fit the data in a pre-defined boundary with a pre-defined boundary (Patro \& Sahu, 2015). The transformation that has the identical range $(0$ - 1$)$ normalizes criteria score are as follows:

$$
\mathrm{A}^{\prime}=\left(\frac{A-\min \text { value of } A}{\text { max value of } A-\min \text { value of } A}\right) *(D-C)+C
$$

Where, A' contains Min-Max Normalized data one, the pre-defined boundary is [C - 0, D - 1].

\subsection{Criteria Weighting and Categories Aggregate}

The model uses criteria weightage and category aggregate (Table 3.1) which has been established through the budget allocation process (BAP) method (Greco et al., 2019; Nardo, Saisana, Saltelli, \& Tarantola, 2005) to ascertain the impact value of each criterion and category on tree vandalism incidence. A total of 18 experts in tree care management have been involved in these processes. 
Table 3.1: Criteria Weightages Used in Tree Vandalism Model

\begin{tabular}{|c|c|c|}
\hline Criteria (k) & Criteria Weighting (b) & Category Aggregate (c) \\
\hline Specific Motive And Action & & 33.89 \\
\hline 1. Location of tree & 3.61 & \\
\hline Size of tree & 3.17 & \\
\hline 3. Tree health condition & 3.11 & \\
\hline Tree growth rates & 3.11 & \\
\hline Species of tree & 2.78 & \\
\hline The owner of the tree & 2.72 & \\
\hline Tree characteristic & 2.72 & \\
\hline Tree debris & 2.61 & \\
\hline Tree value & 2.06 & \\
\hline 10. Age of tree & 1.94 & \\
\hline Ideology And Practices & & 32.78 \\
\hline 1. Level of knowledge & 3.67 & \\
\hline Rule and regulations & 3.67 & \\
\hline Information on tree benefits & 3.22 & \\
\hline Design and layout & 3.11 & \\
\hline Tree care monitoring & 3.06 & \\
\hline Tree maintenance approaches & 3.06 & \\
\hline Tree maintenance status & 2.94 & \\
\hline Religious and cultural beliefs & 2.72 & \\
\hline Coordination and cooperation & 2.67 & \\
\hline Demographic (age) & 2.33 & \\
\hline 11. Socio-economic status & 1.83 & \\
\hline Victim Of Circumstances & & 33.33 \\
\hline 1. Conflict with other activities & 3.78 & \\
\hline $\begin{array}{l}\text { 2. Infrastructure upgrading/extension \& } \\
\text { urbanization/development }\end{array}$ & 3.78 & \\
\hline A priority of space usage & 3.72 & \\
\hline Trees cause interference/obstruction & 3.67 & \\
\hline A tree for structure attachment & 3.67 & \\
\hline Tree as a protective structure & 2.39 & \\
\hline Event and occasion & 3.00 & \\
\hline Use of tree parts for other purposes & 2.67 & \\
\hline Rate of the human population & 2.39 & \\
\hline 10. Memorial display & 2.39 & \\
\hline 11. A tree without a protective structure & 3.06 & \\
\hline
\end{tabular}

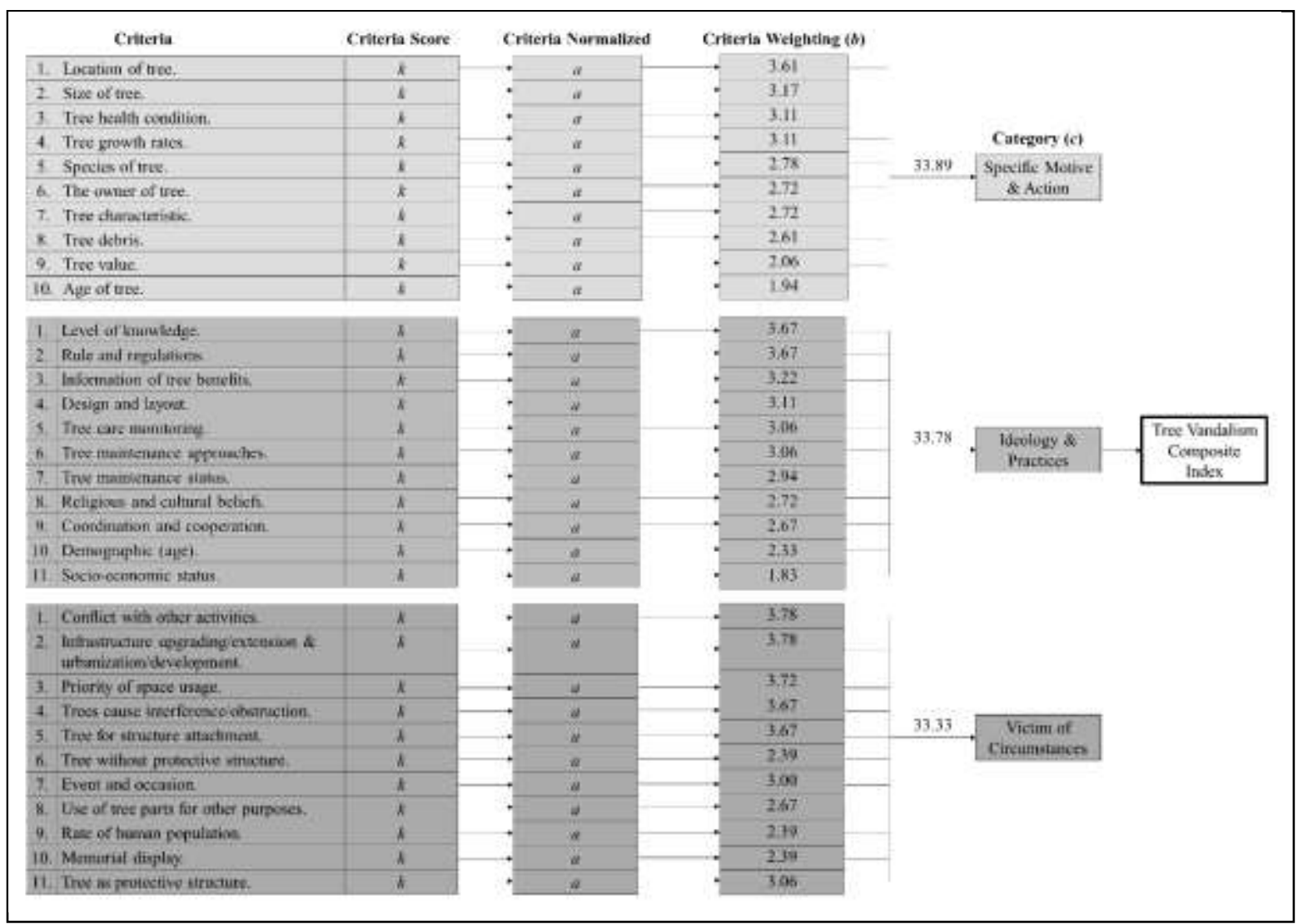

Figure 3.1: The Tree Vandalism Model Framework 
Hence, the value of tree vandalism index can be generated through multiplied each normalized criteria score and criteria weighting with category aggregate (Equation). By this equation, each rated criteria of tree vandalism gained index incidence value of its own. Figure 3.1 shows the framework that used the criteria normalized score, identified items weighting, and category aggregate to measure the tree vandalism composite index.

\subsection{Tree Vandalism Classification}

The classification of tree vandalism status determined by a typical scale used by most analysts, assessors, and evaluators for measuring a stage or the occurrence of a matter (Welle, Birkmann, Rhyner, Witting, \& Wolfertz, 2012; Baptista, 2014; Balica, Wright, \& van der Meulen, 2012). The value of tree vandalism composite index indicator developed base on maximum criteria normalized score. The classification based on generated tree vandalism composite index value within five index dimensions (table 3.2); 'very low', 'low', 'medium', 'high' and 'very high'. Each dimension assigned a color code that offers the distinct advantage of revealing geospatial relationships and patterns when mapping the index results.

Table 3.2: The Classification of Tree Vandalism Incidence

\begin{tabular}{|c|c|c|c|}
\hline \multicolumn{3}{|c|}{ Explanation } & \multirow[b]{2}{*}{ Classification } \\
\hline $\begin{array}{c}\text { The score of Tree } \\
\text { Vandalism Composite Index }\end{array}$ & $\begin{array}{l}\text { Percentage of Tree } \\
\text { Vandalism Index }\end{array}$ & Indicator & \\
\hline 2,523 to 3,152 & $81 \%-100 \%$ & $\begin{array}{l}\text { Achieve tree vandalism incidence radius } 81 \%-100 \% \\
\text { having a severe level of tree vandalism incidence }\end{array}$ & \\
\hline 1,892 to 2,522 & $61 \%-80 \%$ & $\begin{array}{l}\text { Reach tree vandalism incidence radius } 61 \%-80 \% \text {, } \\
\text { having a high level of tree vandalism incidence }\end{array}$ & \\
\hline 1,262 to 1,891 & $41 \%-60 \%$ & $\begin{array}{l}\text { Reach tree vandalism incidence radius } 41 \%-60 \% \text {, } \\
\text { having a medium level of tree vandalism incidence }\end{array}$ & \\
\hline$<630$ & $<20 \%$ & $\begin{array}{l}\text { Reach tree vandalism incidence under }< \\
20 \% \text {, having a low level of tree vandalism incidence }\end{array}$ & Very \\
\hline
\end{tabular}

\subsection{Conclusion}

TVM uses all tree vandalism incidence data based on the value of each criterion involved and translates it to their status by classification indicator. TVM helps to provide policymakers and tree managers with useful guidance to assess and determine the tree vandalism status of the urban area. It facilitates monitored tree vandalism incidence over time concerning the classification of tree vandalism status as an indicator to monitor changes in the status of tree vandalism, and, whether it heads towards a better status or otherwise. Thus, the results generated from TVM are expected to provide evidence and awareness for policymakers and tree managers towards managing the urban tree.

\section{Acknowledgments}

The author thanks expert respondents for their input in the model development. The authors also acknowledged Universiti Teknologi MARA in providing the Bestari Perdana Research Grant for this research (600-IRMI/PERDANA 5/3 BESTARI (056/2018).

\section{References}

Balica, S. F., Wright, N. G., \& van der Meulen, F. (2012). A flood vulnerability index for coastal cities and its use in assessing climate change impacts. Natural Hazards (Vol. 64). https://doi.org/10.1007/s11069-012-0234-1

Baptista, S. R. (2014). Design and use of composite indices in assessment of climate change vulnerability and resilience. United States Agency International Development (USAID), (July), 53pp.

Camacho-Cervantes, M., Schondube, J. E., Castillo, A., \& MacGregor-Fors, I. (2014). How do people perceive urban trees? Assessing likes and dislikes in relation to the trees of a city. Urban Ecosystems, 1-13. https://doi.org/10.1007/s11252-014-0343-6 
Foster, \& Blaine. (1978). Urban tree survival: trees in the sidewalk. Journal of Arboriculture, 4(August), 14-17.

Friar, B., Gibson, K., \& Vollebregt, H. (2012). Park Vandalism in Christchurch. Research Methods in Geography.

Gilbertson, P., \& Bradshaw, A. D. (1985). Tree survival in cities: The extent and nature of the problem. Arboricultural Journal, 9(2), 131-142. https://doi.org/10.1080/03071375.1985.9746706

Greco, S., Ishizaka, A., Tasiou, M., \& Torrisi, G. (2019). On the Methodological Framework of Composite Indices: A Review of the Issues of Weighting, Aggregation, and Robustness. Social Indicators Research, 141(1), 61-94. https://doi.org/10.1007/s11205-017-1832-9

Gwedla, N., \& Shackleton, C. M. (2015). The development visions and attitudes towards urban forestry of officials responsible for greening in South African towns. Land Use Policy, 42, 17-26. https://doi.org/10.1016/j.landusepol.2014.07.004

Hasan, R., Othman, N., \& Ismail, F. (2017). Social Factors Influencing Hazardous Street Trees at Selected City Council in Malaysia. Environment-Behaviour Proceedings Journal, 2(February), 25-27. https://doi.org/10.21834/e-bpj.v2i5.696

Koeser, A., Hauer, R., Norris, K., \& Krouse, R. (2013). Factors influencing long-term street tree survival in Milwaukee, WI, USA. Urban Forestry and Urban Greening, 12(4), 562568. https://doi.org/10.1016/j.ufug.2013.05.006

Long. (2003). Scarred Trees. Victoria, Canada.

Malek, N., \& Mariapan, M. (2009). Visitors' perception on vandalism and safety issues in a Malaysian urban park. Theoretical and Empirical Researches in Urban Management, 4(13), 93-107.

Mazziotta, M., \& Pareto, A. (2013). Methods for constructing composite indicators: one for all or all for one? Rivista Italiana Di Economia Demografia e Statistica, LXVII(AprileGiugno), 67-80. Retrieved from http://www.sieds.it/listing/RePEc/journl/2013LXVII_N2_10_Mazziotta_Pareto.pdf

Miller, R. H., \& Miller, R. W. (1991). Planting survival of selected street tree taxa. Journal of Arboriculture, 17(7), 185-191. https://doi.org/10.1016/0006-3207(92)90963-N

Moore. (2013). Ring-Barking and Girdling : How Much Vascular Connection Do You Need Between Roots and Crown? The 14th National Street Tree Symposium, (Table 1), 8796.

Nardo, M., Saisana, M., Saltelli, A., \& Tarantola, S. (2005). Tools for composite indicators building. Analysis, EUR 21682(December), 134. https://doi.org/10.1038/nrm1524

Nowak, D., Joe, M., \& Beatty, R. (1990). Newly planted street tree growth and mortality. Journal of Arboriculture, 16, 124-129. Retrieved from http://nrs.fs.fed.us/pubs/jrnl/1990/ne_1990_nowak_001.pdf

Nowak, Kuroda, \& Crane. (2004). Tree mortality rates and tree population projections in Baltimore, Maryland, USA. Urban Forestry \& Urban Greening, 2(3), 139-147. https://doi.org/10.1078/1618-8667-00030

OCHA. (2015). West Bank : Largest Number of trees recorded vandalized by Israeli settlers in a single incident since 2005. The Monthly Humanitarian Bulletin, (January)

Patro, S. G. K., \& Sahu, K. K. (2015). Normalization: A Preprocessing Stage, (April). https://doi.org/10.17148/IARJSET.2015.2305

Pepper, H. W. (2008). Girdling, Constriction and Ring Barking. Trees in focus (Vol. APN13). USA: AAIS

Richardson, E., \& Shackleton, C. M. (2014). The extent and perceptions of vandalism as a cause of street tree damage in small towns in the Eastern Cape, South Africa. Urban Forestry and Urban Greening, 13(3), 425-432. https://doi.org/10.1016/j.ufug.2014.04.003

Roman, L. A., Battles, J. J. \&, \& McBride, J. R. (2014). The balance of planting and mortality in a street tree population. Urban Ecosystems, 17(2), 387-404. https://doi.org/10.1007/s11252-013-0320-5

Trout, R., \& Brunt, A. (2014). Protection of Trees from Mammal Damage.

Welle, T., Birkmann, J., Rhyner, J., Witting, M., \& Wolfertz, J. (2012). World Risk Index 2012: concept, updating and results. (M. W. Beck, J. Birkmann, J. Rhyner, T. Welle, M. Witting, J. Wolfertz, ... K. Radtke, Eds.). Berlin: Bündnis Entwicklung Hilft. Retrieved from www.entwicklung-hilft.de

Zaragoza Hernández, A. Y., Cetina Alcalá, V. M., López López, M. Á., Chacalo Hilú, A., Isla de Bauer, M. de L. de la, Alvarado Rosales, D., \& González Rosas, H. (2015). Identificación de daños en el arbolado de tres parques del Distrito Federal TT - Identification of tree damages of three parks of Mexico City. Revista Mexicana de Ciencias Forestales, 6(32), 63-82. Retrieved from

http://www.scielo.org.mx/scielo.php?script=sci_arttext\&pid=S2007-11322015000600063\&lang=pt\%0Ahttp://www.scielo.org.mx/pdf/remcf/v6n32/2007-1132-remcf-6-32-00063.pdf 